\title{
Correction to: Prevalence and clinical impact of malaria infections detected with a highly sensitive HRP2 rapid diagnostic test in Beninese pregnant women
}

\author{
Valérie Briand ${ }^{1,2^{*}} \mathbb{0}$, Gilles Cottrell ${ }^{2}$, Nicaise Tuikue Ndam², Xavier Martiáñez-Vendrell ${ }^{3}$, Bertin Vianou ${ }^{4}$, \\ Atika Mama ${ }^{4}$, Bienvenue Kouwaye ${ }^{4}$, Sandrine Houzé2, ${ }^{2,}$ Justine Bailly ${ }^{5}$, Erasme Gbaguidi ${ }^{4}$, Darius Sossou ${ }^{4}$, \\ Achille Massougbodji ${ }^{4}$, Manfred Accrombessi ${ }^{4}, 6$, Alfredo Mayor ${ }^{3}$, Xavier C. Ding ${ }^{7}$ and Nadine Fievet ${ }^{2}$
}

\section{Correction to: Malar J (2020) 19:188 https://doi.org/10.1186/s12936-020- 03261-1}

Following publication of the original article [1], the authors flagged that there is an error present in Table 5.

As a result of an error in the statistical program used to categorize women based on 'gravidity', some 'secundigravidae' have been (erroneously) classified as 'multigravidae'.
Consequently, the performance values based on gravidity, which are secondary results, are incorrect in the table.

To amend this error, the corrected Table 5 is provided in this correction.

Finally, in addition to the above, the author name Nicaise Tuikue Ndam has been misspelled in the article as 'Nicaise Tuike Ndam'; please find the corrected name in this correction.

The authors apologize for any inconvenience caused.

The original article can be found online at https://doi.org/10.1186/s1293

\section{6-020-03261-1.}

*Correspondence: valerie.briand@ird.fr

${ }^{2}$ Université de Paris, MERIT, IRD, 75006 Paris, France

Full list of author information is available at the end of the article

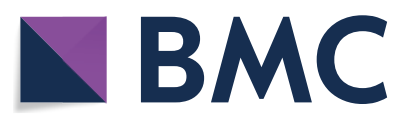

(c) The Author(s) 2020. This article is licensed under a Creative Commons Attribution 4.0 International License, which permits use, sharing, adaptation, distribution and reproduction in any medium or format, as long as you give appropriate credit to the original author(s) and the source, provide a link to the Creative Commons licence, and indicate if changes were made. The images or other third party material in this article are included in the article's Creative Commons licence, unless indicated otherwise in a credit line to the material. If material is not included in the article's Creative Commons licence and your intended use is not permitted by statutory regulation or exceeds the permitted use, you will need to obtain permission directly from the copyright holder. To view a copy of this licence, visit http://creativeco mmons.org/licenses/by/4.0/. The Creative Commons Public Domain Dedication waiver (http://creativecommons.org/publicdomain/ zero/1.0/) applies to the data made available in this article, unless otherwise stated in a credit line to the data. 
Table 5 Performance of uRDT and CRDT against qPCR, according to the trimester of pregnancy, gravidity, and presence of fever

\begin{tabular}{|c|c|c|c|}
\hline & uRDT & cRDT & P value $^{a}$ \\
\hline \multicolumn{4}{|l|}{ Sensitivity (95\% CI) } \\
\hline 1st trimester & $57.0 \%(47.1-66.5)$ & $38.3 \%$ (29.1-48.2) & $<10^{-3}$ \\
\hline 3rd trimester & $64.9 \%(47.5-79.8)$ & $54.1 \%(36.9-70.5)$ & 0.05 \\
\hline $\begin{array}{l}\text { Delivery (peripheral } \\
\text { blood) }\end{array}$ & $83.3 \%$ (58.6-96.4) & $61.1 \%(35.7-82.7)$ & 0.05 \\
\hline $\begin{array}{l}\text { Delivery (placental } \\
\text { blood) }\end{array}$ & $40.0 \%(12.2-73.8)$ & $40.0 \%(12.2-73.8)$ & - \\
\hline $\begin{array}{l}\text { Primi and Secundi- } \\
\text { gravidae }\end{array}$ & $57.4 \%(42.2-71.7)$ & $44.7 \%(30.2-59.9)$ & 0.01 \\
\hline Multigravidae $(3+)$ & $61.6 \%(52.5-70.2)$ & $44.0 \%(35.1-53.2)$ & $<10^{-3}$ \\
\hline Asymptomatic & $60.8 \%(52.3-68.9)$ & $43.4 \%(35.1-51.9)$ & $<10^{-3}$ \\
\hline Symptomatic* & $66.7 \%(41.0-86.7)$ & $50.0 \%(26.0-74.0)$ & 0.08 \\
\hline \multicolumn{4}{|l|}{ Specificity (95\% CI) } \\
\hline 1st trimester & $91.5 \%$ (86.9-94.9) & $95.7 \%(92.1-98.0)$ & 0.003 \\
\hline 3rd trimester & $95.7 \%(92.0-98.0)$ & $97.1 \%(93.8-99.0)$ & 0.08 \\
\hline $\begin{array}{l}\text { Delivery (peripheral } \\
\text { blood) }\end{array}$ & $96.4 \%(92.2-98.7)$ & $97.6 \%(94.0-99.3)$ & 0.16 \\
\hline $\begin{array}{l}\text { Delivery (placental } \\
\text { blood) }\end{array}$ & $91.3 \%$ (86.3-94.9) & $92.4 \%(87.6-95.8)$ & 0.41 \\
\hline $\begin{array}{l}\text { Primi and Secundi- } \\
\text { gravidae }\end{array}$ & $93.5 \%$ (88.5-96.9) & $96.1 \%(91.8-98.6)$ & 0.04 \\
\hline Multigravidae $(3+)$ & $93.7 \%$ (91.4-95.5) & $95.6 \%(93.7-97.1)$ & 0.003 \\
\hline Asymptomatic & $94.6 \%(92.3-96.4)$ & $97.1 \%(95.3-98.4)$ & $<10^{-3}$ \\
\hline Symptomatic ${ }^{b}$ & $92.2 \%(82.7-97.4)$ & $93.7 \%$ (84.8-98.3) & 0.32 \\
\hline
\end{tabular}

RECIPAL study, 2014-2017

a Comparison of URDT and CRDT performance using McNemar test for matched pairs. Exact binomial confidence intervals were computed

b Presence of fever (axillary temperature $\geq 37.5^{\circ} \mathrm{C}$ ) or history of fever in the preceding $24 \mathrm{~h}$, whether or not infected with malaria

\section{Author details}

${ }^{1}$ Institut de Recherche Pour le Développement (IRD), University of Bordeaux, Inserm, UMR 1219, 146 Rue Léo-Saignat, 33076 Bordeaux Cedex, France.

${ }^{2}$ Université de Paris, MERIT, IRD, 75006 Paris, France. ${ }^{3}$ ISGlobal, Hospital Clínic of Barcelona, Universitat de Barcelona, Barcelona 08036, Spain. ${ }^{4}$ Institut de Recherche Clinique du Bénin (IRCB), Cotonou, Benin. ${ }^{5}$ AP-HP, Centre National de Référence sur le paludisme, Hôpital Bichat-Claude-Bernard, 75017 Paris, France. ${ }^{6}$ Faculty of Infectious and Tropical Diseases, Disease Control Department, London School of Hygiene and Tropical Medicine, WC1E 7HT London, UK. ${ }^{7}$ FIND, 1202 Geneva, Switzerland.

Published online: 07 September 2020

\section{Reference}

1. Briand V, Cottrell G, Ndam NT, Martiáñez-Vendrell X, Vianou B, Mama A, Kouwaye B, Houzé S, Bailly J, Gbaguidi E, Sossou D, Massougbodj A, Accrombessi M, Mayor A, Ding XC, Fievet N. Prevalence and clinical impact of malaria infections detected with a highly sensitive HRP2 rapid diagnostic test in Beninese pregnant women. Malar J. 2020;19:188. https ://doi.org/10.1186/s12936-020-03261-1.

\section{Publisher's Note}

Springer Nature remains neutral with regard to jurisdictional claims in published maps and institutional affiliations.
Ready to submit your research? Choose BMC and benefit from:

- fast, convenient online submission

- thorough peer review by experienced researchers in your field

- rapid publication on acceptance

- support for research data, including large and complex data types

- gold Open Access which fosters wider collaboration and increased citations

- maximum visibility for your research: over $100 \mathrm{M}$ website views per year

At $\mathrm{BMC}$, research is always in progress.

Learn more biomedcentral.com/submissions 